\title{
Pengaruh Brand Image, Brand Awareness dan Brand Trust Terhadap Minat Beli Pepsodent pada Mahasiswa Konsentrasi Kewirausahaan STIE Indragiri Rengat
}

\author{
Roky Apriansyah', Meilya Karya Putri' ${ }^{2)}$, Walmi Sholihat ${ }^{3)}$ \\ ${ }^{122) 3)}$ Program Studi Manajemen, Sekolah Tinggi Ilmu Ekonomi Indragiri Rengat \\ R.Soeprapto 14.,Rengat, Indragiri Hulu, Riau \\ Correspondence email: ${ }^{1)} \underline{\text { rokyapriansyah@stieindragiri.ac.id }}{ }^{2)}$ meilya@ stieindragiri.ac.id ${ }^{3)} \underline{\text { walmisholihat @ stieindragiri.ac.id }}$
}

\begin{abstract}
The development of the toiletries industry in Indonesia is currently running so rapidly that it creates increasingly fierce competition, business people are also required to be more creative and have a competitive advantage compared to their competitors. The toiletry industry is one of the many industries that experience very tight competition, this can be shown by the increasing number of business actors entering this industrial sector. This study aims to determine the effect of brand image, brand awareness and brand trust on the buying interest of Pepsodent in entrepreneurship concentration students, Stie Indragiri Rengat. The population in this study were all students of the Entrepreneurship Concentration of STIE Indragiri Rengat, Indragiri Hulu Regency, Odd Semester, Academic Year 2020/2021, totaling 63 people. The sampling technique used is the census method. The results of hypothesis testing are: first, Brand Image partially influences the buying interest of Pepsodent in entrepreneurship concentration students of STIE Indragiri Rengat. Second, Brand Awareness partially affects the buying interest of Pepsodent in entrepreneurship concentration students of STIE Indragiri Rengat. Third, Brand Trust partially influences the buying interest of Pepsodent in entrepreneurship concentration students of STIE Indragiri Rengat.
\end{abstract}

Keywords: Interest In Buying Pepsodent, Brand Image, Brand Awareness and Brand Trust

\section{Pendahuluan}

Bertambahnya jumlah penduduk menjadi semakin besarnya kebutuhan warga dalam kehidupan tiap hari. Perihal tersebut menjadi sesuatu konsekuensi untuk para produsen yang muncul dalam upaya menanggapi pemenuhan kebutuhan warga dengan hadirnya persaingan diantara bermacam industri terkait. Perusahaan- perusahaan diberbagai zona berupaya menawarkan bermacam produk serta jasa guna memenuhi kebutuhan warga yang sangat kompleks. Perkembangan industri toiletries begitu pesat sehingga menciptakan persaingan dan terus menjadi kompetitif. Pelaku bisnis dituntut supaya lebih kreatif dan memiliki keunggulan kompetitif dibanding dengan para kompetitornya. Industri toilitries ialah industri yang menghadapi persaingan ketat, terbukti dari banyaknya pelaku usaha yang bergerak dibidang ini. Banyak industri di Indonesia baik lokal ataupun multinasional yang bergerak di bisnis toiletries diantaranya PT Unilever, PT Ultra Prima Abadi, PT Wings Surya, PT Lion Wings, P \& Gram, serta yang lain.

Toiletries ialah suatu indutri yang memproduksi kebutuhan harian warga, terkhusus perawatan diri( personal care) semacam sabun mandi, shampo, pasta gigi dan lain sebagainya. Industri ini banyak diminati disebabkan pasar Indonesia yang menjanjikan apabila dilihat dari segi besarnya penduduk dan produk personal care ialah produk digunakan setiap hari. Banyaknya merk serta tipe pasta gigi, pastinya akan memberi peluang tiap konsumen untuk memilih produk yang cocok dengan kebutuhan serta keinginannya, sementara untuk para pelaku bisnis sendiri pasti saja perihal ini menjadi sesuatu beban serta permasalahan yang lumayan besar. Mereka tidak dapat lagi melaksanakan bisnisnya tanpa perhitungan serta perencanaan matang sebab banyaknya kompetitor. Mengindikasikan meningkatnya persaingan memperebutkan pangsa pasar. Pasta gigi ialah salah satu produk personal care yang menarik untuk diteliti karena industry pasta gigi di Indonesia berkembang cukup pesat seiring dengan pertumbuhan jumlah penduduk, daya beli warga yang meningkat serta pemahaman akan perawatan gigi yang meningkat. Apabila dilihat dari data merek pasta gigi yang ada di pasaran Indonesia yang tampak jelas bahwa saat ini dipasarkan lebih dari 10 merek pasta gigi dengan berbagai macam merk dan diproduksi perusahaan-perusahaan besar diantaranya merek pasta gigi Ciptadent, Pepsodent, close-up, fresh \& white, Zact, Formula, ABCdent, Oral-B, Enzime, Siwak F, Sensodent, dll.

Top brand pasta gigi Pepsodent dalam kurun waktu lima tahun terakhir mengalami fluktuasi, ini mengindikasikan bahwa keputusan pembelian terhadap produk tersebut juga berfluktuasi, hal ini dikarenakan indikator pengukuran top brand sendiri adalah perilaku konsumen terhadap suatu produk seperti penggunaan produk oleh konsumen saat ini atau produk yang terakhir dipakai (last utilization) dan pertimbangan penggunaan produk oleh konsumen dimasa mendatang (future goal). Tujuan penelitian ini adalah untuk mengetahui pengaruh brand image, brand awareness dan brand trust secara simultan terhadap minat beli pepsodent pada mahasiswa konsentrasi kewirausahaan STIE Indragiri Rengat. 


\section{Minat Beli}

Minat beli merupakan Hasrat yang muncul setelah konsumen menerima rangsangan dari barang yang dilihatnya, kemudian timbul keinginan untuk membeli dan memiliki (Kotler \& Amstrong, 2012); Schiffman \& Kanuk (2009) mengataka bahwa minat beli merupakan kemampuan psikologis dalam diri tiap individu yang berdampak pada sebuah aksi. Minat beli dijadikan tolak ukur penilaian minat konsumen untuk membeli suatu produk, dimana semakin tinggi minat beli akan meningkatkan kemungkinan konsumen untuk membeli suatu produk.

\section{Brand Image}

Tjiptono (2008) mengungkapkan makna merek sebagai nama, istilah, simbol, atau lambing, desain, warna, gerak, atau kelompok atribut-atribut benda lainnya yang diharapkan bisa memberikan karakter dan sebagai pembeda terhadap benda pesaing. Kotler \& Keller (2007) juga menerangkan bahwa merek adalah nama, istilah, tanda, atau lambang, atau desain, atau kombinansinya

\section{Brand Awareness}

Brand Awareness adalah cara konsumen untuk megingat suatu produk barang atau jasa dengan merk tertentu baik melelaui iklan maupun secara langsung dengan bantuan kata kunci (Eka, 2014). Saryadi (2015) menerangkan Kesadaran merek adalah tahapan pertama yang yang terjadi dalam menerima, melihat dan mendengar informasi suatu barang tertentu yang dijelaskan melalui beberapa cara yaitu : sadar merk, kenal merk, ingat merk, dan berada pada pemikiran konsumen.

\section{Brand Trust}

Menurut Rizan (2012), Brand Trust merupakan pola pikir konsumen tentang suatu barang dalam hal memberi kepuasan berdasarkan pengalaman, pemakaian, dan interaksi sesuai dengan harapan yang diinginkan konsumen itu sendiri (Mizan, 2012). Hal ini terjadi jika ekspektasi sesuai dengan realita yang ingin dicapai oleh konsumen. Menurut Erna (2008) kepercayaan merupakan keyakinan spesifik dibandingkan dengan Intregritas (kejujuran pihak yang dipercaya dan kemampuan menepati janji), Benevolence (perhatian dan motivasi yang dipercaya untuk bertindak sesuai dengan kepentingan yang mempercayai mereka), Competency (kemampuan pihak yang dipercaya untuk melaksanakan kebutuhan yang mempercayai) dan Predictability (konsistensi perilaku pihak yang dipercaya).

\section{Metode}

Penelitian ini dilakukan di STIE Indragiri Rengat Kabupaten Indragiri Hulu. Waktu penelitian pada 2020.062020.12. Populasi dalam penelitian ini ialah mahasiswa Konsentrasi Kewirausahaan Sekolah Tinggi Ilmu Ekonomi Indragiri Rengat Kabupaten Indragiri Hulu Semester Ganjil TA. 2020/2021 dan Data Sekunder yaitu data yang diperoleh dari lokasi Penelitian yaitu Sekolah Tinggi Ilmu Ekonomi Indragiri Rengat Kabupaten Indragiri Hulu. Teknik pengambilan sampel yang digunakan adalah metode sensus. Jenis data yang digunakan dalam penelitian ini adalah data primer. Pengumpulan data dilakukan dengan cara menyebarkan kuesioner secara langsung kepada responden yang bersangkutan.

Untuk menguji hipotesis dalam penelitian ini menggunakan metode regresi linear berganda, untuk lebih jelasnya dapat dilihat dalam persamaa satu berikut :

$\mathrm{Y}=\alpha+\beta 1 \mathrm{X} 1+\beta 2 \mathrm{X} 2+\beta 3 \mathrm{X} 3+\mathrm{e}$

Keterangan: $\mathrm{Y}=$ minat beli; $\alpha=$ konstanta; $\beta=$ koefisien regresi; $\mathrm{X}_{1}=$ variabel Brand Imagel $\mathrm{X}_{2}=$ variabel Brand Awareness; $\mathrm{X}_{3}=$ variabel Brand Trust $; \mathrm{e}=$ error

\section{Hasil}

Hasil uji validitas terhadap pernyataan-pernyataan (item) (X dan Y) sebagai berikut : Brand Image (X1), Brand Awareness (X2), dan Brand Trust (X3) dari 15 pernyataan seluruhnya valid dan tidak terdapat pertanyaan yang tidak valid sebab nilai r-hitung >r-tabel pada $\alpha=0,05$ dimana r-tabel $=0,248$. Hasil uji reliabilitas hanya dilakukan atas data yang telah diuji validitasnya dan dinyatakan valid. Aturan umum yang dipakai cronbach's alpha $\geq 0,60$ sudah mencerminkan yang reliable.

Tabel 1

Hasil Pengujian Reliabilitas

\begin{tabular}{llrrr}
\hline No & \multicolumn{1}{c}{ Instrument Variabel Penelitian } & Nilai Cronbach's Alpha & \multicolumn{1}{c}{ Nilai Kritis } & Kesimpulan \\
\hline 1 & Brand Image (X1) & 0,827 & 0,6 & Reliabel \\
2 & Brand Awareness (X2) & 0,837 & 0,6 & Reliabel \\
3 & Brand Trust $(\mathrm{X} 3)$ & 0,754 & 0,6 & Reliabel \\
4 & Minat Beli Pepsodent (Y) & 0,791 & 0,6 & Reliabel \\
\hline
\end{tabular}

Sumber : Data Olahan 
Roky Apriansyah et al., Pengaruh Brand Image, Brand Awareness dan Brand Trust Terhadap Minat Beli Pepsodent pada Mahasiswa Konsentrasi Kewirausahaan STIE Indragiri Rengat

Berdasarkan uji reliabilitas disimpulkan bahwa semua instrumen pernyataan yang digunakan untuk mengukur variabel-variabel yang dianalisis dalam penelitian ini dinyatakan reliable, hal ini terlihat dari nilai Cronbach's Alpha seluruh variabel yang diteliti lebih besar dari 0.60. Tabel 2 terlihat nilai Asymp. Sig. (2-tailed) 0,200>0.05. maka dapat disimpulkan bahwa data berdistribusi secara normal.

Tabel 2

Hasil Uji Normalitas Data

\begin{tabular}{|l|r|}
\hline & Unstandardized Residual \\
\hline N & 63 \\
\hline Normal Parameters Mean & 0.0000000 \\
\hline Std. Deviation & 1.94874102 \\
\hline Most Extreme Differences Absolute & 0.098 \\
\hline Positive & 0.096 \\
\hline Negative & -0.098 \\
\hline Test Statistic & 0.098 \\
\hline Asymp. Sig. (2-tailed) & 0.200 \\
\hline
\end{tabular}

Tabel 3

Hasil Uji Multikolinieritas

\begin{tabular}{|l|r|r|l|}
\hline \multirow{2}{*}{ Model } & \multicolumn{2}{|c|}{ Collinearity Statistics } \\
\cline { 2 - 4 } & Tolerance & VIF & Keterangan \\
\hline Brand Image (X1) & 0.480 & 2.081 & Tidak terdapat Multikolinieritas \\
\hline Brand Awareness (X2) & 0.567 & 1.762 & Tidak terdapat Multikolinieritas \\
\hline Brand Trust (X3) & 0.433 & 2.311 & Tidak terdapat Multikolinieritas \\
\hline
\end{tabular}

Sumber : Data Olahan

Analisis data diatas, diperoleh nilai tolerance untuk seluruh variabel independen $>0,10$ dan VIF < 10; maka dapat disimpulkan keseluruhan variabel independen tersebut bebas dari multikolinieritas. Gambar 1 scatterplot pada gambar di atas dapat dilihat bahwa titik-titik menyebar secara acak, serta tersebar baik diatas maupun dibawah angka nol pada sumbu Y. Hal ini dapat disimpulkan bahwa tidak terjadi heterokedastisitas pada model regresi.

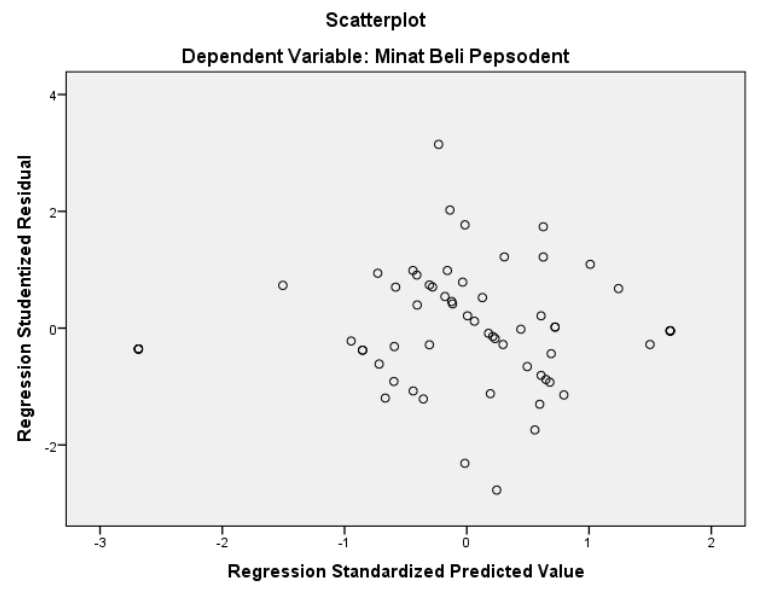

Sumber : Data Olahan

\section{Gambar 1 Hasil Uji Heteroskedastisitas}

Tabel 4

Hasil Analisis Regresi Berganda

\begin{tabular}{|c|c|c|c|c|c|}
\hline \multirow{2}{*}{ Model } & \multicolumn{2}{|c|}{ Unstandardized Coefficients } & \multirow{2}{*}{$\frac{\text { Standardized Coefficients }}{\text { Beta }}$} & \multirow{2}{*}{$\mathrm{t}$} & \multirow{2}{*}{ Sig. } \\
\hline & Beta & Std. Error & & & \\
\hline (Constant) & 2.965 & 5.104 & & 0.581 & 0.563 \\
\hline Brand Image (X1) & 0.309 & 0.092 & 0.322 & 3.380 & 0.001 \\
\hline Brand Awareness (X2) & 0.273 & 0.081 & 0.296 & 3.380 & 0.001 \\
\hline Brand Trust (X3) & 0.379 & 0.102 & 0.371 & 3.699 & 0.000 \\
\hline
\end{tabular}

Sumber : Data Olahan 
Roky Apriansyah et al., Pengaruh Brand Image, Brand Awareness dan Brand Trust Terhadap Minat Beli Pepsodent pada Mahasiswa Konsentrasi Kewirausahaan STIE Indragiri Rengat

Berdasarkan Tabel 4 yang didapat dari hasil analisi menggunakan spss versi 23, maka didapat persamaan regresi linear berganda adalah: $\mathrm{Y}=2.965+0.309 \mathrm{X} 1+0.273 \mathrm{X} 2+0.169 \mathrm{X} 3+\mathrm{e}$

Persamaan regresi tersebut dapat dijeleskan sebagai berikut:

1. Nilai konstanta (a) sebesar 7.556 artinya adalah apabila variabel independen diasumsikan nol (0), maka minat beli pepsodent sebesar 7.556.

2. Nilai koefisien X1 sebesar 0.309 menunjukkan bahwa variabel brand image berpengaruh positif terhadap minat beli pepsodent, atau dengan kata lain jika ditingkatkan nilai brand image sebesar $1 \%$ maka akan menigkat minat beli pepsodent sebesar 0.309 .

3. Nilai koefisien X2 sebesar 0.273 menunjukkan bahwa variabel brand awareness berpengaruh positif terhadap minat beli pepsodent, atau dengan kata lain jika ditingkatkan nilai brand awareness sebesar $1 \%$ maka akan menigkat minat beli pepsodent sebesar 0.273 .

4. Nilai koefisien X3 sebesar 0.379 menunjukkan bahwa variabel brand trust berpengaruh positif terhadap minat beli pepsodent, atau dengan kata lain jika ditingkatkan nilai brand trust sebesar $1 \%$ maka akan menigkat minat beli pepsodent sebesar 0.379 .

Tabel 5

Hasil Uji Koefisien Determinasi $\left(\mathbf{R}^{2}\right)$

\begin{tabular}{|c|c|c|r|r|}
\hline Model & R & R Square & Adjusted R Square & Std. Error of the Estimate \\
\hline 1 & 0.862 & 0.743 & 0.730 & 1.998 \\
\hline
\end{tabular}

Sumber : Data Olahan

Tabel 5 diperoleh nilai $\mathrm{R}$ square sebesar 0.334. artinya adalah bahwa sumbangan pengaruh variabel independen terhadap variabel dependen sebesar $74,4 \%$ sedangkan sisanya sebesar $25,6 \%$ dipengaruhi oleh variabel lain yang tidak dimasukkan dalam model penelitian ini.

\section{Simpulan}

Hasil penelitian ini mengungkapkan bahwa brand image, brand awareness, brand trust secara simultan maupun secara parsial berpengaruh signifikan terhadap minat beli pepsodent pada mahasiswa konsentrasi kewirausahaan STIE Indragiri Rengat.

\section{Daftar Pustaka}

Amstrong, Gary \& Philip, Kotler. (2012) Dasar-Dasar Pemasaran. Jilid I, Alih Bahasa Alexander Sindoro dan Benyamin Molan. Jakarta: Penerbit Prenhalindo.

Eka. (2014). Faktor-faktor yang Mempengaruhi Brand Loyalty pada Web Airasia di Surabaya.

Ferrinadewi, Erna. 2008. Merek dan Psikologi Konsumen. Cetakan pertama. Yogyakarat: Graha Ilmu

Kotler, Philip and Kevin Lane Keller, 2016. Marketing Managemen, 15th Edition, Pearson Education,Inc.

Rizan, M., B. Saidani, dan Y. Sari. 2012. Pengaruh Brand Image dan Brand Trust Terhadap Brand Loyalty Teh Botol Sosro. Jurnal Riset Manajemen Sains Indonesia, 3(1), pp. 1-17.

Saryadi, (2015) Pengaruh Brand Awareness, Brand Asosiation dan Advertesing Effections Terhadap Keputusan Pembelian Produk Smartphone Samsung.

Schiffman, Leon G., dan Kanuk, Leslie Lazar. 2009. Perilaku Konsumen. Alih bahasa Zulkifli Kasip. Jakarta : PT. Indeks Group Gramedia.

Tjiptono, Fandy, 2015 . Brand Management \& Strategy. Yogyakarta : Andi 